\title{
"Organization" in the Lettres Philosophiques of Louis Bourguet compared to the writings of Charles Bonnet
}

\author{
By Olivier Rieppel
}

\begin{abstract}
"... Louis Bourguet, a Swiss naturalist from Neuchâtel, a correspondent of Leibniz and Vallisnieri, a distinguished and badly ignored naturalist, who preceded Bonnet in the discovery of natural parthenogenesis and in the acceptance of preformation ..."
\end{abstract}

$\left(\right.$ Schiller, 1974) ${ }^{1}$

Indeed, Bourget had discussed parthenogenesis before Bonnet ${ }^{2}$, but so had others $^{3}$, and as Réaumur remarked ${ }^{4}$, ist was not until Bonnet's ${ }^{5}$ work that parthenogenesis was experimentally demonstrated and thus established as a biological fact. There are, however, a number of other interesting correspondences in the views of Louis Bourguet and Charles Bonnet, younger by one generation.

Louis Bourguet ${ }^{6}$, son of Jean Bourguet and Catherine Rey, was borne in Nîmes (Languedoc, France) on 23 April 1678. Following the revocation of the Edict of Nantes, the protestant family left France for Geneva, Lausanne, and finally Zurich. Louis settled in Neuchâtel in 1704, and in late 1731 was offered the chair of philosophy and mathematics there. He was in contact with many illustrious personalities of his time, amongst which Leibniz figures most prominently; other correspondents included Vallisnieri, Réaumur, and J. J. Scheuchzer. Louis Bourguet died in Neuchâtel on 31 December 1742 .

With his Lettres Philosophiques (1729), Bourguet addressed once again the famous analogy of the formation of crystals and organized beings. This analogy was derived from an atomistic background, and reappeared later in the writings of Georges Buffon and Pierre-Louis Moreau de Maupertuis. Bonnet identified this analogy as a cornerstone of epigenetic theories of embryogenesis, which formed the target of his life-long polemics ${ }^{7}$. Jacques Roger ${ }^{8}$ briefly discussed the Lettres Philosophiques, emphasizing the complexity of Bourguet's model of embryonic development, which combines elements of the doctrines of pre-existence and preformation. In particular, 
J. Roger considered it probable that Buffon may have borrowed his concept of the «moules intérieurs» from Bourguet ${ }^{9}$. Joseph Schiller ${ }^{10}$, on the other hand, stressed the elements of pre-existence and the resulting similarities of the theories of Bourguet and of Bonnet, in particular the concept of a preexisting organic machine. It is common to both authors and rooted in a mechanistic approach to embryogenesis: "Once the machine was started, they were all Cartesians" (Schiller, 1980) ${ }^{11}$.

Correspondences in the views of Bourguet and Bonnet include the doctrine of emboitement; the conception of the primordial germ as being in a 'fluid', 'transparent', and 'folded' condition; the rejection of animalculism and correlated with it the identification of the spermatozoa as parasites; as well as the idea, that the seminal fluid provides the first nutriment for the developing germ. However, on the basis of published material it is impossible to demonstrate a direct influence of the works of Bourguet on Charles Bonnet. First, Bonnet quotes Bourguet's Lettres Philosophiques very rarely only, and if he does, his main concern is to assert his independence ${ }^{12}$ from this "talented observer" 13 whose "imagination indulged in organizing everything". ${ }^{14}$ Secondly, Bourguet and Bonnet may independently have been subject to similar influences. A case in point is the conception of the primordial germ. Bourguet cites Swammerdam and Malpighi in support of ovism ${ }^{15}$. Bonnet, on the other hand, had read Swammerdam's Biblia naturae with great delight ${ }^{16}$, and must have found the description of the 'fluid' 'transparent' and 'folded' germ there ${ }^{17}$. Yet, he repeatedly stressed the importance of A.v. Haller's ${ }^{18}$ studies on the development of the chick, and admits that it was Haller's influence which induced him to think of the primordial germ as of an "organized fluid". ${ }^{20}$ Indeed, the influence of early embryologists such as Swammerdam, Malpighi ${ }^{21}$, and Harvey ${ }^{22}$ may have reached Bourguet and Bonnet independently along multiple pathways. However, convergences in the views of these two men are frequent and particularly striking in those instances where Bonnet's conjectures converge upon those of Bourguet, but are at variance with the views of his friend A.v. Haller. This observation results from a close examination of Bourguet's Lettres Philosophiques in the light of Bonnet's conception of 'organized beings'.

It is hardly surprising that Bourguet, an advocate of Leibniz' Monadolo$g y$, accepted the doctrine of the scala naturae:

«... il y a une gradation entre les Corps Organisés...» (Bourguet, 1729) ${ }^{23}$. 
If, in accordance with Leibnitian metaphysics, the échelle des êtres is viewed as a unifying concept in natural philosophy, reducing the multiplicity of material appearances to the unity of the Divine Plan of Creation ${ }^{24}$, the consequences are as obvious as disturbing:

«Tout est organisé dans la Matière» (Bourguet, 1729) ${ }^{25}$.

Indeed, Bourguet believed ${ }^{26}$ that the occurrence of nails, hairs and teeth in humans demonstrates a gradual transition from the degree of organization of a crystal to that of a fossil or of a living being. But if there is no break, no dichotomy between the realms of the inorganic and of the organic, it is difficult to see what the essence of life, of sensitivity and animality (or irritability in Bonnet's terms) could be. It is therefore hardly surprising that both Bourguet and Bonnet searched criteria other than mere organization to distinguish living from dead matter, although such criteria turned against the philosophers, as they inevitably threatened to disrupt the continuity of the all-embracing scala naturae. The dilemma is obvious in Bonnet's reflections on the distinction of inorganic from organic forms on the basis of different modes of growth, to which he added a word of caution:

«Mais ne prononçons pas qu’il y a ici un saut, une lacune: la lacune n’est que dans nos connoissances actuelles» (Bonnet, 1768) ${ }^{27}$.

Leibniz had paved the way to this escape in a letter to Pierre Varignon, which became public on the occasion of the dispute between Samuel König and Maupertuis at the Berlin Academy of Sciences in 1751. In this letter, Leibniz had stated that, on metaphysical grounds, continuity has to be expected even in those instances where human perception reveals nothing but saltations.

The criteria used by Bourget, and by Bonnet, to distinguish living from dead matter are essentially the same. Comparing the shapes of a stalactite or stalagmite and of a fossil such as a belemnite, or comparing the formation of a crystal and of an organism, Bourguet noted ${ }^{28}$ a striking difference in the degree of regularity and symmetry. The superior, indeed insurpassed regularity and symmetry of living beings could not result from contingent properties of matter; rather, they were interpreted as evidence of Divine design, preordained from the beginning by the creation of pre-existent germs which grow by virtue of a «méchanisme organique». ${ }^{29}$ The formation of 
crystals can be explained by contingent properties of matter («la figure des molécules») and by the laws of movement («loix générales du mouvement») ${ }^{30}$. But the formation of a living being by virtue of the «méchanisme organique» involves more, namely a vital principle («principe actif») ${ }^{31}$, which acts according to final causes. For both, Bourguet and Bonnet, it is the call for final causes which was the motive for the adoption of the doctrine of pre-existing germs, created $a b$ initio and predetermined to undergo regular development. In his attacks against materialists, Bonnet ${ }^{32}$ time and again emphasized the insufficience of purely physical laws and forces for the formation of the "Tout organisé».

In view of his finalist outlook, it is hardly surprising to find Bourguet's «principe actif» to be derived from Leibniz' Monadology ${ }^{33}$. This relativizes J.Schiller's claim of a Cartesian background of Bourguet's model of embryogenesis (see above). By the time Bonnet was expounding a similar view, he was able to submit a physical concept for the «principe actif» or, as he called it, "principe vital» ${ }^{34}$ : the «irritabilité», defined by his friend A.v. Haller as an intrinsic property of the «fibre animale». ${ }^{35}$ For Bonnet, the «fibre élémentaire» ${ }^{36}$ was the ultimate unit of organization, while the doctrine of a uniform gradation of organized beings led him to suggest the possible occurrence of irritability in plants ${ }^{37}$, despite claims to the contrary, e.g. by A.v. Haller.

The doctrine of pre-existing germs reduces the problem of generation to one of nutrition and growth ${ }^{38}$. Here again, Bourguet and Bonnet converged on a distinction of organic from inorganic formation, maintaining that organisms grow by intussuszeption rather than by juxtaposition as crystals do ${ }^{39}$. However, there are observational data which seemed to refute the doctrine of pre-existence as well as the call for final causes: these include individual variability, the effects of inheritance and of hybridization, as well as malformations.

Neither Bourguet, nor Bonnet, were willing to admit-as A.v. Haller did - that malformations were preformed by the benevolent Creator; they had thus to admit accidental causes capable to interfere with the Divine Plan of Creation ${ }^{40}$. The effects of heredity, on the other hand, could not be accounted for by intrinsic properties of the pre-existing germ, and thus had to be attributed to an extrinsic cause. Thence follows the theory of the double function of the seminal fluid as supported by Bourguet as well as by Bonnet, although the latter found himself contradicted by A.v. Haller again. On one side, the "most subtle parts" of the seminal fluid would act as agents of 
fertilization, imparting to the germ the impetus for movement, i.e. for development ${ }^{41}$. On the other side, the more substantial fractions of the seminal fluid would serve as first nutriment, imprinting individual parental characteristics on the germ ${ }^{42}$. As the seminal fluid derives from a source outside the germ, it was natural to expect the latter to be penetrated by pores, which would permit the entry of the first nutriment ${ }^{43}$. Bonnet even stimulated Lazzaro Spallanzani to search for such pores, who indeed claimed to have observed them in amphibian eggs ${ }^{44}$.

It must be stressed that the aspects outlined above constitute but a partial concurrence of the theories expounded by Bourguet and later by Bonnet. As mentioned above, Bourguet's views are rather complex, and entail the concept of an internal mould, whereas Bonnet, frightened by the example of Buffon, rejected such an "obscure mechanism" and had recourse to demonstrated physical principles instead, i.e. to "attractive forces", in order to explain the assimilation of nutritive molecules ${ }^{45}$. But correspondences can be observed in very basic aspects, such as the distinction of organic from inorganic mechanism as well as the correlated doctrine of preexisting germs; and there is even a concurrence of inconsistencies such as the combination of the call for final causes, regulating development according to Divine foresight, with the admittance of accidental causes, capable to interfere with the Plan of Creation causing malformations. Such observations warrant closer scrutinity in future analyses of a possible influence of Bourguet's Lettres Philosophiques on the views of Charles Bonnet. Analysis needs not to be confined to the notion of organization, but may be expanded to the investigation of parallels between Bourguet's «théorie de la terre» and the Palingénésie Philosophique of Charles Bonnet, which both start out from early versions of catastrophism.

Notes

1 Schiller, J., Queries, answers, and unsolved problems in Eighteenth century biology. In: History of Science 12 (1974), p. 189.

2 Bourguet, L., Lettres Philosophiques sur la Formation des Sels et des Crystaux et sur la Génération \& le Méchanisme Organique des Plantes et des Animaux, p. 77-78, Amsterdam 1729.

3 Marx, J., Charles Bonnet contre les Lumières. In: Studies on Voltaire and the Eighteenth Century 156 (1976), p.50.

4. Réaumur, R.-A.-F. de, Mémoires pour servir à l'Histoire des Insectes, Vol. VI, p. 536-537, Paris 1742 . 
5 Bonnet, C., Traitté d'Insectologie; ou Observations sur les Pucerons, Paris 1745.

6 Leu, H.J., Allgemeines Helvetisches, Eydgenössisches, oder Schweizerisches Lexicon, Vol.IV, p.243-246, Zürich 1750. See also Meister, L., Helvetiens berühmte Männer in Bildnissen, 2nd edition, Vol. II, p. 306-313, Zürich 1799. Lutz, M., Nekrolog denkwürdiger Schweizer aus dem achtzehnten Jahrhundert, p.62-63, Aarau 1812, Türler, H., Godet, M., Attinger, V., Historisch-biographisches Lexikon der Schweiz, Vol.II, p.331. Neuenburg 1924. Poggendorff, J.C., Biographisch-Literarisches Handwörterbuch zur Geschichte der exacten Wissenschaften, Vol. I, p. 260-261, Amsterdam 1970.

7 Rieppel, O., Atomism, epigenesis, preformation and pre-existence: a clarification of terms and consequences. In: Biol. J.Linn. Soc., Lond., in press.

8 Roger, J., Les Sciences de la Vie dans la Pensée Française du XVIII ${ }^{e}$ Siècle, 2nd edition, Paris 1971.

9 Ibid., p. 546.

10 Schiller, J., Queries ..., In: History of Science 12 (1974), p. 184-199. See also Schiller, J., Physiology and Classification. Historical Relations, Paris 1980.

11 Schiller, J., Physiology and Classification, p. 72; 1980.

12 Bonnet, C., Considération sur les Corps Organisés, seconde édition, Vol.II, p.233-234, Amsterdam 1768.

13 Sonntag, O. (Ed.), The Correspondence between Albrecht von Haller and Charles Bonnet, p. 821, Berne 1983. Letter from Bonnet to Haller dated 25 May 1769.

14 Bonnet, C., Considérations..., Vol. I, p. 189; 1768.

15 Bourguet, L., Lettres Philosophiques..., p. 88; 1729.

16 Savioz, R. (Ed.), Mémoires Autobiographiques de Charles Bonnet de Genève, p.55, Paris 1948.

17 Swammerdam, J., Bibel der Natur, p. 5, 6, 115, Leipzig 1752.

18 Haller, A.v., Sur la Formation du Cæeur dans le Poulet, Lausanne 1758. Haller stressed the fluidity and transparency of the germ and its parts during early development stages (Premier Mémoire, p. 23, 31, 105, 210, 249; Second Mémoire, p. 48, 64, 118, 175, 179, etc.); the parts of the germ are also described as being folded in their primordial condition (Second Mémoire, p. 174).

19 Bonnet, C., Considérations..., Vol. I, p. 108; 1768. See also Bonnet, C., Contemplation de la Nature, vol.I, p. 165, Amsterdam 1764.

20 Bonnet, C., Considérations..., Vol. I, p. 118; 1768.

21 Adelmann, H. B., Marcello Malpighi and the Evolution of Embryology. Vol.II, p. 846, 849, Ithaca 1966. The fluid is considered by Malpighi to be nature's "prime material" (p. 866). Malpighi is cited both by Bourget, L., Lettres Philosophiques..., p. 88; 1729; as well as by Bonnet, C., Considérations..., Vol.I., p.87; 1768. See also Savioz, R. (Ed.), Mémoires Autobiographiques..., p. 56; 1948.

22 Harvey, W., Disputations touching the generation of animals. Translated with introduction and notes by G. Whitteridge, London 1981. The transparency of the early embryo is stressed on p.111.

23 Bourguet, L., Lettres Philosophiques..., p. 56; 1729.

24. Marx, J., Charles Bonnet..., p. 358-361; 1976. See also Bonnet, C., Contemplation..., Vol. I, p. 3, 242, Vol.II, p. 74-77; 1764 .

25 Bourguet, L., Lettres Philosophiques..., p. 58; 1729. 
Ibid., p. 58 .

27 Bonnet, C., Considérations..., Vol. I, p. 191; 1768.

28 Bourguet, L., Lettres Philosophiques..., p. 7, 38, 64; 1729.

29 Ibid., p.xxxvi, xxxviii, 36, 64, etc.

30 Ibid., p. 41.

31 Ibid., p.xxxix-xl, 66, 149, 166-167.

32 Bonnet, C., Considérations..., Vol. I, p. 83-85; 1768. See also Bonnet, C., Contemplation..., Vol.I, p.xxiv, 154, 248; 1764. Bonnet, C., La Palingénésie Philosophique, Vol.I, p.76, 356, Geneva 1769. Sonntag, O. (Ed.), Correspondence..., p. 885-907; 1983.

Bourguet, L., Lettres Philosophiques..., p. xxxix-xl, 166-167; 1729.

Bonnet, C., Considérations..., Vol. I, p. 138; 1768.

Sonntag, O. (Ed.), Correspondence..., p.49; 1983. Letter from Haller to Bonnet dated 6 September 1754.

36 Bonnet, C., Considérations..., Vol. I, p. 57, 143; 1768.

Bonnet, C., Palingénésie..., Vol. I, p. 364; 1769. See also Bonnet's designation of the germ as a folded net of elementary fibres in Considérations..., Vol. I, p. 56-57; 1768.

37 Bonnet, C., Contemplation..., Vol. II, p. 73-74; 1764.

38 Bonnet, C., Considérations..., Vol. I, p. 63; 1768.

39 Bourguet, L., Lettres Philosophiques..., p. 70-72; 1729. It was noted above that Bourguet considered nails, hairs and teeth to grow by apposition as crystals do; see also Roger, J., Les Sciences de la Vie..., p. 376; 1971. Bonnet, C., Considérations..., Vol. I, p. 60, 133; 1768. Bonnet emphasized intussuszeptional growth in organized beings. He later revised his terminology of intussuszeptional, juxtapositional and appositional growth in Bonnet, C., Palingénésie..., Vol. I, p. 405-410; 1769.

40 Bourguet, L., Lettres Philosophiques..,, p. 142; 1729. Bonnet, C., considérations..., Vol. II, p. 248, 261; 1768. Bonnet's admittance of accidental causes was at variance with Haller's opinion; see Sonntag, O. (Ed.), Correspondence..., p.476, 498; 1983. Letters exchanged during the period from 12. Febr. 1766 to 27 May 1766.

41 Bourguet, L., Lettres Philosophiques..., p. 149-150; 1729. The mixture of the male and female seminal fluids blends with the fluid surrounding the germ and imparts movement to the germ's heart. Bonnet, C., Considération..., Vol. II, p. 195; 1768. Bonnet supported the doctrine of the "double semence" during early years of his theorizing, but dropped it following Haller's refutation of that doctrine; according to his revised version of the mechanism of fertilization, the male seminal fluid awakens the irritability of the germ's heart. The observation that the heart is the first part of the embryo to move can be traced back to Aristotle's investigation of the development of the chick.

42 Bourguet, L., Lettres Philosophiques..., p. 154, 160-165; 1729. The mixture of the male and female seminal fluid transmits characters of both parents. Bonnet, C., Considérations..., Vol. II, p. 197, 207-209; 1768. The male semen transmits paternal characteristics only; maternal characteristics are transmitted to the germ via the blood of the female. Bonnet's views on the functions of the male seminal fluid converge upon those of Bourguet, but are at variance with the theory espoused by Haller. See Sonntag, O. (Ed.), Correspondence..., p. 110-111, 117, 177-178; 1983.

43 Bourguet, L., Lettres Philosophiques..., p. 150; 1729.

Bonnet, C., Considérations..., Vol. I, p. 57; 1768. 
44 Castellani, C. (Ed.), Lettres à M. l'Abbé Spallanzani de Charles Bonnet, p. 56, 324, 407, Milano 1971.

45 Bonnet, C., Considérations..., Vol. I, p. 55, 83; 1768.

\section{Zusammenfassung}

Die Lettres Philosophiques (1729) von Louis Bourguet werden verglichen mit dem Werk des um eine Generation jüngeren Genfer Naturforschers Charles Bonnet, besonders hinsichtlich des Begriffes der Organisation lebender Materie. Es werden auffällige Parallelen im Denken der beiden Naturforscher aufgezeigt, die sich nicht nur auf die gemeinsame Befürwortung der Doktrin prä-existenter Keime erstrecken, sondern auch Inkonsistenzen der Theorie einschlieBen. Es wird vorgeschlagen, einer möglichen Beeinflussung Bonnets durch Bourguet mehr Aufmerksamkeit zu schenken.

PD Dr. O. Rieppel

Paläontologisches Institut und Museum der Universität

Künstlergasse 16

CH-8006 Zürich 